\title{
Valsartan Prevented Neointimal Hyperplasia and Inhibited SRSF1 Expression and the TLR4-iNOS-ERK-AT1 Receptor Pathway in the Balloon-injured Rat Aorta
}

\author{
Yonghong LI ${ }^{1 *}$, Junjie GUO ${ }^{1 *}$, Haichu YU ${ }^{1}$, Xin LIU ${ }^{1}$, Jingwei ZHOU ${ }^{2}$, Xianming CHU ${ }^{1}$, \\ Qingke XU ${ }^{1}$, Tingru SUN ${ }^{3}$, Liang PENG ${ }^{1}$, Xi YANG ${ }^{1}$, Xilong TANG ${ }^{1}$ \\ *These authors contributed equally to this work \\ ${ }^{1}$ Department of Cardiology, Affiliated Hospital of Qingdao University, Qingdao, China, \\ ${ }^{2}$ Department of Emergency, Affiliated Hospital of Qingdao University, Qingdao, China, \\ ${ }^{3}$ Department of Cardiology, Zibo First Hospital, Zibo, China
}

Received September 24, 2020

Accepted April 22, 2021

Epub Ahead of Print June 2, 2021

\begin{abstract}
Summary
Valsartan has the potential to attenuate neointimal hyperplasia and to suppress the inflammatory response. This study aimed to evaluate the role of valsartan in neointimal hyperplasia and the toll-like receptor 4 (TLR4)-nitric oxide synthase (NOS) pathway in the balloon-injured rat aorta. Forty-eight Wistar rats were randomly allocated to three groups: sham control (control), balloon-injured group (surgery), and balloon-injured+valsartantreated group (valsartan). Rats were killed at 14 and 28 days after balloon-injury, and then the aortic tissues were collected for morphometric analysis as well as for measurements of the mRNA or protein expression of angiotensin II, angiotensin II type 1 (AT1) receptor, angiotensin II type 2 (AT2) receptor, TLR4, endothelial nitric oxide synthase (eNOS), inducible NOS (iNOS), serine/arginine-rich splicing factor 1(SRSF1) and extracellular signal regulated kinase (ERK). Valsartan at a dose of $20 \mathrm{mg} / \mathrm{kg} /$ day markedly decreased neointimal hyperplasia in the aorta of balloon-injured rats, and significantly reduced the mRNA or protein expression of TLR4, AT1 receptor, SRSF1 and phosphorylated-ERK ( $p$-ERK) as well as the aortic levels of iNOS (all $p<0.05$ ). Moreover, valsartan increased the eNOS level and AT2 receptor mRNA and protein expression levels (all $p<0.05$ ). Valsartan prevented neointimal hyperplasia and inhibited SRSF1 expression and the TLR4-iNOS-ERK-AT1 receptor pathway in the balloon-injured rat aorta.
\end{abstract}

\section{Key words}

Valsartan • Aorta • Neointimal hyperplasia • Balloon injury • Tolllike receptor 4 - Nitric oxide synthase

\section{Corresponding author}

Yonghong Li. Department of Cardiology, Affilicated Hospital of Qingdao University, No. 59 Haier Road, Qingdao 266003, China. E-mail: liyonghong662020@126.com

\section{Introduction}

Percutaneous coronary intervention (PCI) is a generally accepted therapy for treating coronary heart disease. Restenosis remains an important complication with the use of angioplasty and stents. Within 6 months, restenosis occurs in $32-55 \%$ of all angioplasties, dropping to $17-41 \%$ in the bare metal stent area (Buccheri et al. 2016). However, a new complication instent restenosis (ISR) arises from neointimal hyperplasia. Although the use of drug-eluting stents reduce the incidence of ISR to $5 \%$-10\% (Paramasivam et al. 2020), ISR remains a serious concern as late stent complications and drug eluting stent (DES) and ISR treatment continue to be challenging complications for interventional cardiologists (Alraies et al. 2017).

Neointimal formation after vascular injury is the critical pathological process of ISR. Activated vascular smooth muscle cells (VSMCs) respond to local stimulation and migrate from the media into the lumen of the vessel, participating in the process of restenosis. Serine/arginine-rich splicing factor 1 (SRSF1),

PHYSIOLOGICAL RESEARCH • ISSN 1802-9973 (online) - an open access article under the CC BY-NC-ND 4.0 license (c) 2021 Institute of Physiology of the Czech Academy of Sciences, Prague, Czech Republic Fax +420 241062 164, e-mail: physres@fgu.cas.cz, www.biomed.cas.cz/physiolres 
an essential splicing factor, promotes VSMC proliferation and injury-induced neointima formation. Vascular injury in vivo and proliferative stimuli in vitro were indicated to stimulate SRSF1 expression (Xie et al. 2017). Moreover, local inflammation after vascular injury also contributes to the development of restenosis (Araújo et al. 2015, Joviliano et al. 2011, Yoneda et al. 2013). Toll-like receptor 4 (TLR4), a member of the pattern recognition receptor family, participates in the inflammatory response after vascular injury (Den Dekker et al. 2010, Zou et al. 2019), and has been implicated as a potential clinical biomarker in patients who develop in-stent restenosis (Liang et al. 2016). Decreased nitric oxide (NO) production due to endothelial denudation leads to VSMC proliferation and migration. Endogenous NO is usually generated by endothelial nitric oxide synthase (eNOS), inducible NOS (iNOS), and neuronal NOS (nNOS) (Forstermann and Sessa 2012). Induction of iNOS production subsequently promotes the inflammatory response and accelerates restenosis (Chyu et al. 1999). In contrast, activation of eNOS can decrease neointimal formation after arterial injury (Janssens et al. 1998). Therefore, the TLR4-iNOS pathway can provide an emerging target for the prevention of restenosis.

Angiotensin II, a major mediator of the renninangiotensin system, acts through angiotensin II type 1 (AT1) and angiotensin II type 2 (AT2) receptors. Valsartan is regarded as a widely used AT1 receptor blocker (Huang et al. 2014). Our previous studies have shown that valsartan can reduce neointimal hyperplasia of the rat aorta via activating the angiotensin-converting enzyme 2 (ACE2)-angiotensin-(1-7)-Mas axis, inhibiting the AT1 receptor, and upregulating heme oxygenase-1 (Li et al. 2012, Li et al. 2014, 2016). Valsartan was proved to exert anti-inflammatory effects in clinical (Kintscher et al. 2010) and experimental (Iwashita et al. 2012, Hadi et al. 2015) studies. Previous study suggested that valsartan-eluting stents can inhibit neointimal hyperplasia post-stent implantation by reducing VSMC proliferation and collagen deposition (Guihua et al. 2010). Clinically, valsartan has yielded a beneficial effect by preventing in-stent restenosis after stenting (Peters 2008). However, the effects of valsartan on neointimal hyperplasia, the upstream signaling pathways of TLR4 and other proinflammatory cytokines in the ballooninjured rat aorta need to be further explored. Therefore, this study sought to evaluate the role of valsartan in neointimal hyperplasia, the TLR4-NOS pathway and SRSF1 expression in the balloon-injured rat aorta.

\section{Materials and Methods}

\section{Drug and reagents}

Valsartan was provided by Novartis Pharma Ltd. (Beijing, China). The angiotensin II radioimmunoassay kit was obtained from the Institute of Radioimmunoassay of the People's Liberation Army General Hospital, China. The NOS reagent kit was obtained from the Nanjing Jiancheng Institute of Biological Engineering, China. Polyclonal anti-TLR4, anti- $\beta$-actin, anti-AT1, anti-AT2, and antiphospho- ERK were provided by Santa Cruz Biotechnology Inc., Santa Cruz, CA, USA. Polyclonal anti-SRSF1 was provided by Thermo Fisher Inc., Waltham, MA, USA.

\section{Animals and experimental protocol}

All the experimental protocols were performed in accordance with the Guidelines for the Care and Use of Laboratory Animals of Qingdao University (Number of Ethic Committee: QYFY WILL 25705). A total of 48 adult male Wistar rats weighing 300-350 g were provided by the Qingdao Animal Center, and housed at a temperature at $22{ }^{\circ} \mathrm{C}$ and $35 \pm 5 \%$ humidity under a 12-h dark-light cycle. All rats were fed on a laboratory diet of rat chow and freely accessed to water. These rats were randomly allocated to three groups: sham control group (control group), balloon-injured group (surgery group), and balloon-injured+valsartan-treated group (valsartan group) ( $\mathrm{n}=16$ in each group). Neointimal hyperplasia of aortas was established using endothelial denudation with a $2 \mathrm{~F}$ balloon dilation catheter. Briefly, rats were anesthetized by $0.6 \%$ sodium pentobarbital $(5 \mathrm{ml} / \mathrm{kg})$ intraperitoneally. The balloon catheter entered the thoracic aorta and abdominal aorta through the left common carotid artery. The balloon was inflated and passed with rotation three times in different directions. The success of aortic denudation was determined by injection of $2 \mathrm{ml} / \mathrm{kg} 0.5 \%$ Evan's blue at $60 \mathrm{~min}$ after surgery (Li et al. 2008). The sham control rats underwent the same surgery except for balloon injury. The valsartantreated rats received $20 \mathrm{mg} / \mathrm{kg} /$ day valsartan (dissoluted in normal saline) via gastric gavage. Treatments started $24 \mathrm{~h}$ before balloon injury and continued until day 14 or day 28 post-surgery. The same volumes of $0.9 \%$ saline solution were administered to the sham control and surgery rats.

Histological analysis

Rats were anesthetized by $0.6 \%$ sodium 
pentobarbital and sacrificed by cervical dislocation at 14 days and 28 days post-surgery, respectively. Thoracic aortic tissues in length of $4-5 \mathrm{~cm}$ were collected immediately. Other harvested aortic tissues were then immediately frozen in liquid nitrogen until a further analysis. Collected aortic tissues were cut into $5-\mu \mathrm{m}$ sections for hematoxylin-eosin (HE) staining and immunofluorescence. Images of neointimal hyperplasia were visualized under a light microscope at $200 \times$ magnification. Morphometric determinations of the intimal and medial thicknesses were quantified using an image analyzer (JEDA801 series, Science-Technology Development Co., China). The expression of SRSF1 protein was detected in immunofluorescence under a fluorescence microscope (DS-Ri2, Nikon Co., Japan) according to the previous report (Zaqout et al. 2020).

\section{Measurement of angiotensin II and NOS in aortic tissues}

Collected thoracic aortic tissues $(35 \mathrm{mg}$ in each group) were homogenized and centrifuged at $3000 \mathrm{rpm}$ for $20 \mathrm{~min}$, and then the supernatant was collected. The aortic angiotensin II levels were determined by a radioimmunoassay kit, according to the manufacturer's protocol. The iNOS and eNOS levels in aortic tissues were detected using chemical methods in accordance with the manufacturer's instructions.

\section{Reverse transcription polymerase chain reaction}

(RT-PCR)TLR4, AT1 receptor, and AT2 receptor mRNA expression levels were detected by the reverse transcription polymerase chain reaction (RT-PCR). Trizol reagent (Invitrogen, Carlsbad, CA, USA) was used to extract total RNA from the frozen aortic samples, according to the manufacturer's protocol. The integrity of extracted RNA was confirmed spectrophotometrically at $260 \mathrm{~nm}$ and $280 \mathrm{~nm}$ wavelengths. GAPDH was chosen as an internal control. The primer sequences were as follows: TLR4 (304 bp), 5'-TGGCATCATCTTCATTGTCC-3' (Forward) and 5'-GTCCACAGCAGAAACCCAGA-3' (Reverse), AT1 receptor (444 bp), 5'-CACCTATGTAAGATCGCTTC-3' (Forward) and 5'-GCACAATCGCCATAATTATCC-3' (Reverse), AT2 receptor (536 bp), 5'-TGAGTCCGCATTTAACTGC-3' (Forward) and 5'-ACCACTGAGCATATTTCTCGGG-3' (Reverse), GAPDH (161 bp), 5'- AGATGGTGAAGGTCGGTGTG3' (Forward) and 5'-CTTGCCGTGGGTAGAGTCAT-3' (Reverse). The reaction was conducted on an ABI PRISM 7000 Sequence System (Applied Biosystems, Foster City,
CA, USA) under the following conditions: $95{ }^{\circ} \mathrm{C}$ for $3 \mathrm{~min}, 98^{\circ} \mathrm{C}$ for $10 \mathrm{~s}, 57^{\circ} \mathrm{C}$ for $10 \mathrm{~s}$, and $72{ }^{\circ} \mathrm{C}$ for $30 \mathrm{~s}$ (total of 40 cycles), then a final extension for $10 \mathrm{~min}$. The amplified PCR product was checked and analyzed by a gel imaging analyzer. Target mRNA expression was normalized to GAPDH mRNA expression for quantification.

\section{Western blot analysis}

Aortic TLR4, AT1 receptor, AT2 receptor, and p-ERK protein expression levels were detected by Western blot analysis. Briefly, $20 \mu \mathrm{g}$ of protein was resolved by sodium dodecyl sulfate-polyacrylamide gel electrophoresis (SDS-PGE), and transferred to a polyvinylidene fluoride membrane. The membranes were blocked with nonfat milk, and then incubated with anti-TLR4 (1:100 dilution), anti-AT1 (1:50 dilution), anti-AT2 (1:50 dilution), anti-phospho-ERK (1:100 dilution), or anti- $\beta$-actin (1:500 dilution), and subsequently incubated with the secondary antibody at 1:1250 dilution. Protein bands were visualized with an enhanced luminescence reagent and visualized using a Flurochem 9900-50 digital gel imaging system (Alpha Innotech Co., San Leandro, CA, USA). The optical density of each band was normalized to that of $\beta$-actin from the same sample.

\section{Statistical analysis}

Statistical analysis was performed using Statistical Product and Service Solutions (SPSS) version 16.0 (SPSS, Inc., Chicago, IL, USA). Values were expressed as the mean \pm standard deviation (SD). For the values of repeated measurements, two-way analysis of variance was performed. A statistical significance was set as $p<0.05$.

\section{Results}

Effects of valsartan on neointimal hyperplasia in the balloon-injured rat aorta

On 14th day post-surgery, compared to the control (Fig. 1A), HE staining showed that most injured surfaces were covered by endothelial cells, and there was a large amount of VSMC proliferation. In addition, the intima was apparently tortuous, and neointimal hyperplasia was predominant (Fig. 1B). On 28th day post-surgery, compared to the control (Fig. 1D), endothelial cells almost covered all injured surfaces, and there was obvious VSMC proliferation as well as 

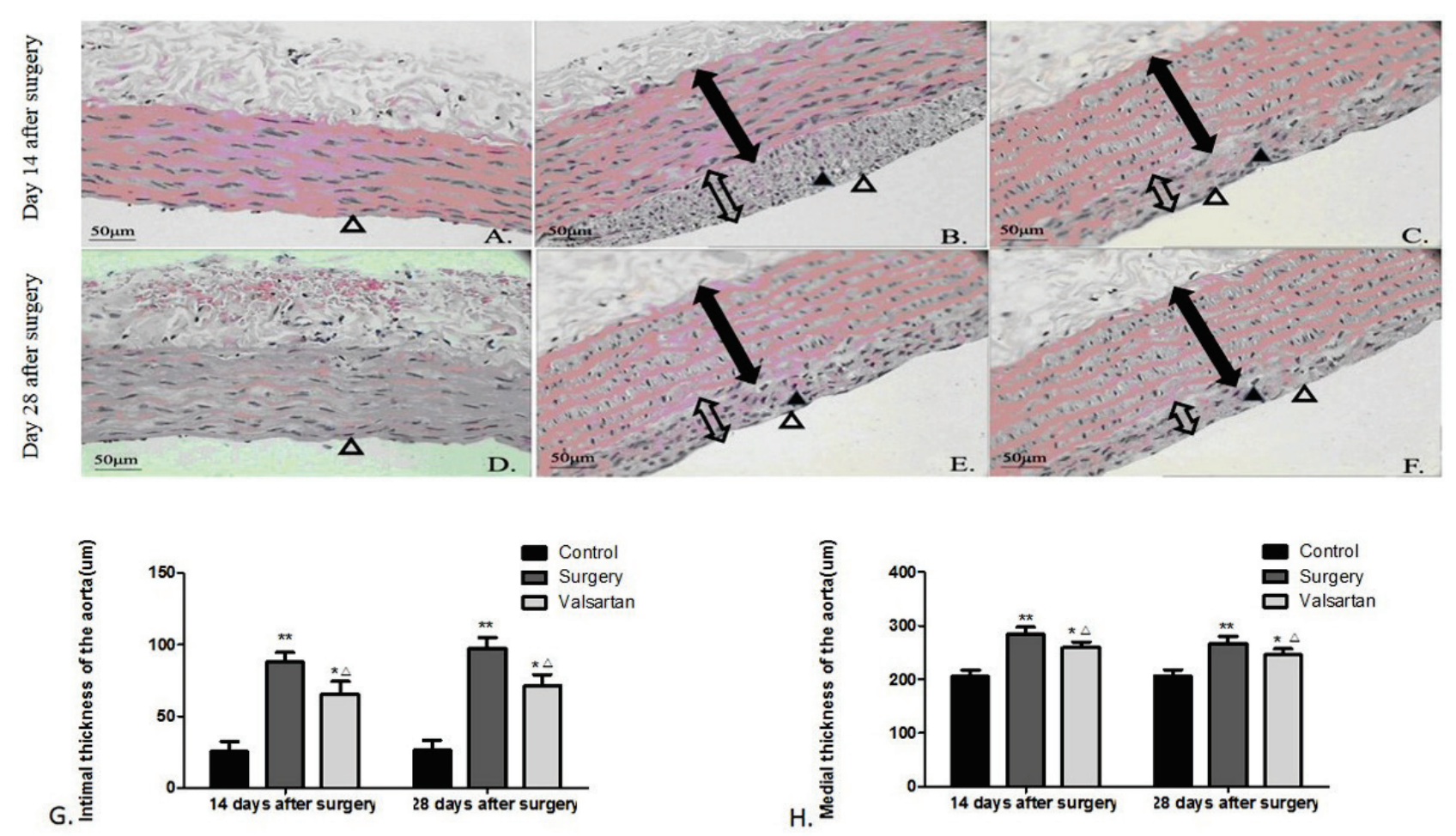

Fig. 1. Representative hematoxylin-eosin staining images of neointimal hyperplasia in different groups (magnification, $\times 200$ ). The sham control rats exhibited a normal intima and media of the aorta at 14 (A) and 28 (D) days after surgery, the balloon-injured rats showed hyperplasic intima with endothelial cells and proliferative VSMCs (B and E), the valsartan-treated rats showed less intimal and medial hyperplasia $(\mathbf{C}$ and $\mathbf{F})$. Image analysis of the intimal $(\mathbf{G})$ and medial $(\mathbf{H})$ thicknesses. Data are shown as the mean $\pm \operatorname{SD}(n=6)$. ${ }^{*} \mathrm{p}<0.05,{ }^{* *} p<0.01 \mathrm{vs}$ the control group, and $\Delta \mathrm{p}<0.05$ vs the surgery group. The solid line with double arrow represented media and the empty line with double arrow represented intima. The solid triangle represented proliferative VSMCs and empty triangle represented endothelial cells.

A.

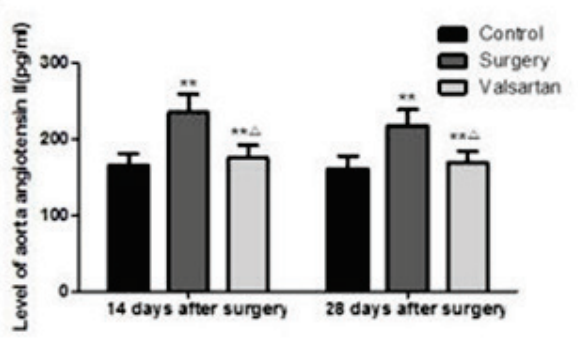

C.

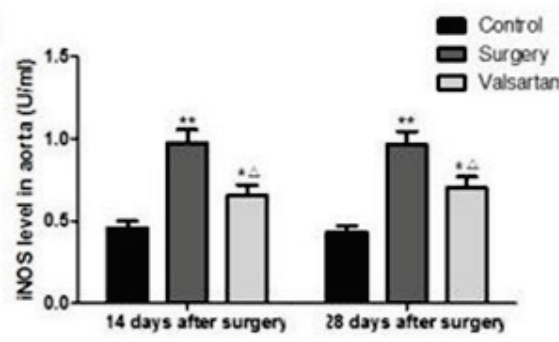

B.

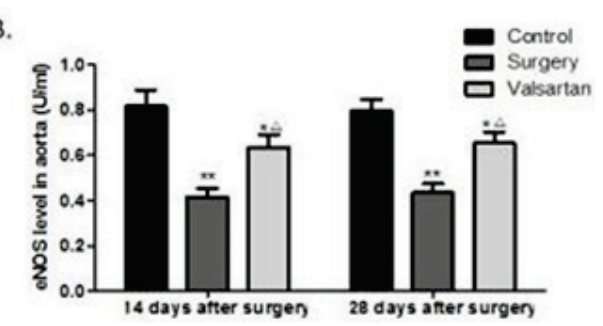

Fig. 2. Effects of valsartan on aortic angiotensin II (A), eNOS (B), and iNOS (C) levels. Data are shown as the mean \pm SD $\quad(n=6) . \quad{ }^{*} p<0.05$, ${ }^{* *} p<0.01$ vs the control group, and $\Delta p<0.05 \mathrm{vs}$ the surgery group. sustained neointimal hyperplasia. An increased extracellular matrix was the main histological change (Fig. 1E). Compared with surgery group, the VSMC proliferation and VSMC migration in valsartan-treated group were obviously attenuated on 14th day (Fig. 1C) and 28th day (Fig. 1F) post-surgery. The image analysis results showed that valsartan significantly attenuated the intimal (Fig. 1G) and medial (Fig. 1H) thicknesses, compared to the untreated balloon-injured rats (all $p<0.01$ ). 
Effects of valsartan on aortic levels of angiotensin II, eNOS, and $\mathrm{NNOS}$

Angiotensin II, eNOS, and iNOS expression levels in the aorta were shown in Fig. 2. On days 14 and days 28 post-surgery, the aortic angiotensin II (Fig. 2A) and iNOS (Fig. 2C) levels of the surgery rats were markedly increased, whereas, the aortic eNOS expression levels (Fig. 2B) in the surgery rats were significantly reduced, compared to those of the sham controls (all $p<0.01)$. In contrast, at both 14 and 28 days post-surgery, the administration of valsartan markedly reduced the aortic levels of angiotensin II and iNOS, and increased the aortic levels of eNOS, compared to the untreated balloon-injured rats (all $p<0.05$ ). However, still increased angiotensin II and iNOS expression levels, and decreased eNOS expression levels were seen in rat aorta of valsartan group compared with controls (all $p<0.05$ ).
Effects of valsartan on aortic TLR4, AT1 receptor, and AT2 receptor $m R N A$ expression

RT-PCR analysis showed that, compared to the sham controls, the TLR4 (Fig. 3A) and AT1 receptor (Fig. 3B) mRNA expression levels were significantly increased in the surgery rats on days 14 and 28 postsurgery (all $p<0.01$ ). In contrast, the mRNA expression of AT2 receptor (Fig. 3C) was markedly reduced in the surgery rats $(p<0.01)$. Importantly, treatment with valsartan for both 14 and 28 days markedly reduced the TLR4 and AT1 receptor mRNA expression, and increased the AT2 receptor mRNA expression, compared to the surgery rats (all $p<0.05$ ). However, compared to the controls, TLR4 and AT1 receptor expression was still increased, and AT2 was decreased in valsartan group (all $p<0.05)$.
A.

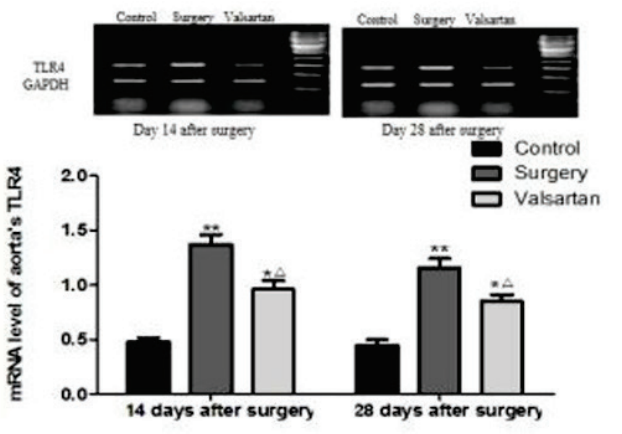

c.

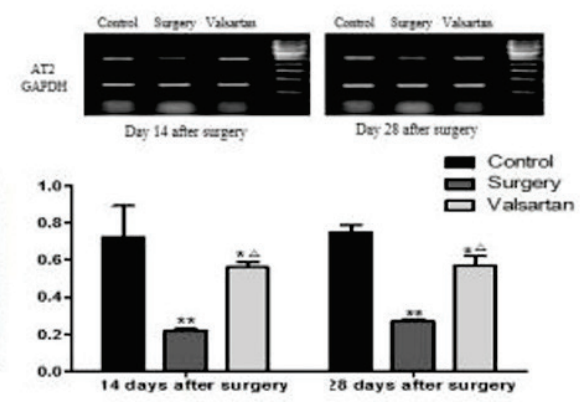

B.
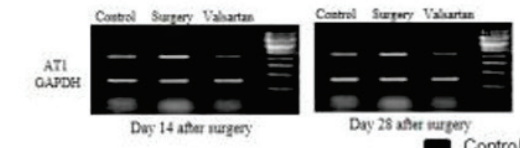

Control

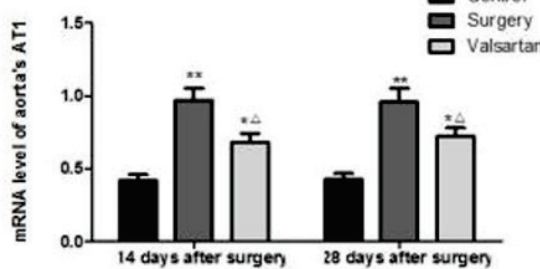

Fig. 3. Effects of valsartan on the aortic TLR4, AT1 receptor, and $A T 2$ receptor mRNA expression. RT-PCR analyses of the aortic TLR4 (A), AT1 receptor (B), and AT2 receptor (C) mRNA expression following valsartan treatment in rats. GAPDH was used as an internal control. Data are shown as the mean \pm SD $\quad(n=6) . \quad{ }^{*} p<0.05$, ${ }^{* *} p<0.01$ vs the control group, and $\Delta p<0.05$ vs the surgery group.

Effects of valsartan on aortic TLR4, AT1 receptor, AT2 receptor, and $p$-ERK protein expression

Effect of valsartan on aortic TLR4, AT1 receptor, AT2 receptor, and p-ERK protein expression was evaluated at 14 and 28 days after surgery using Western blot assay (Fig. 4A). It was shown that aortic TLR4 (Fig. 4B), AT1 receptor (Fig. 4C), and p-ERK (Fig. 4E) protein expressions were markedly upregulated in the surgery rats, whereas, AT2 receptor (Fig. 4D) protein expression was markedly decreased, compared to the sham controls (all $p<0.01$ ). Treatment with valsartan for both 14 and 28 days markedly reduced the protein expression of TLR4, AT1 receptor, and p-ERK as well as increased the AT2 receptor protein expression, compared to the surgery group (all $p<0.05$ ). In addition, compared to the controls, the expression of TLR4, p-ERK and AT1 receptor was still increased, and AT2 receptor was decreased in valsartan group (all $\mathrm{p}<0.05$ ).

\section{Effects of valsartan on aortic SRSF1 protein expression}

SRSF1 protein expression was measured by immunofluorescence assay in control, surgery and valsartan groups at 14 and 28 days after surgery. It was suggested that, aortic SRSF1 expression was increased 
obviously in the surgery rats (Fig. 5B,E) than in the sham controls (Fig. 5A,D). When valsartan given for both 14 (Fig. 5C) and 28 (Fig. 5F) days, SRSF1 expression all decreased significantly in comparison with the surgery group, but it was still higher than the controls.
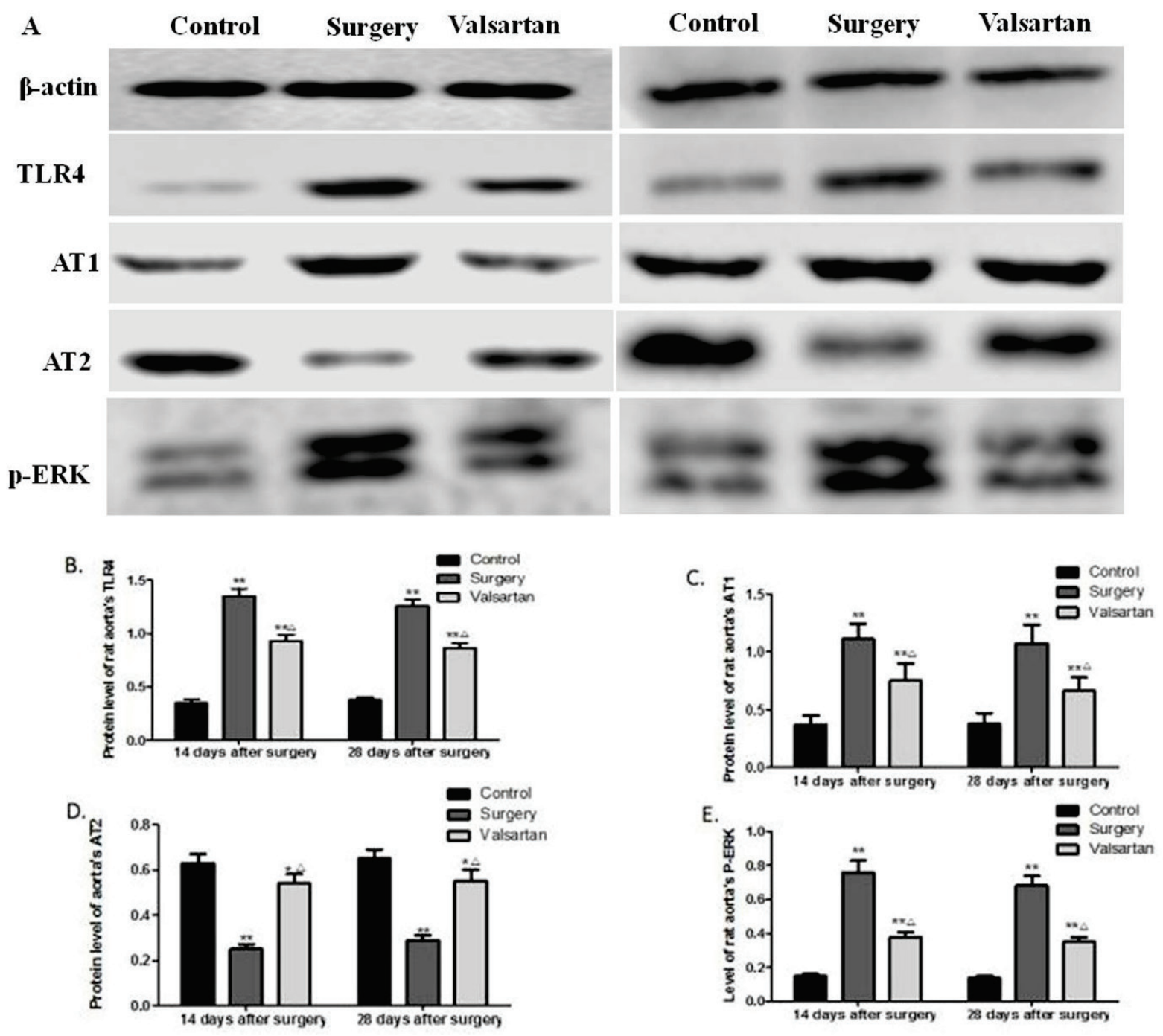

Fig. 4. Effects of valsartan on aortic TLR4, AT1 receptor, AT2 receptor, and p-ERK protein expression. At 14 and 28 days after surgery, protein expression of TLR4, AT1 and AT2 receptors, and p-ERK was evaluated by Western blot assay (A). Quantifications of TLR4 (B), AT1 receptor $(\mathbf{C})$, AT2 receptor $(\mathbf{D})$, and $\mathrm{p}$-ERK $(\mathbf{E})$ protein expression relative to that of $\beta$-actin. Data are shown as the mean \pm SD $(\mathrm{n}=6) .{ }^{*} p<0.05,{ }^{* *} p<0.01$ vs the control group, and $\triangle p<0.05$ vs the surgery group.

\section{Discussion}

The results of the current study indicated that: 1) valsartan at a dose of $20 \mathrm{mg} / \mathrm{kg} /$ day treated ballooninjured rats for both 14 and 28 days significantly inhibited the neointimal hyperplasia and reduced the aortic SRSF1 expression, 2) valsartan decreased the aortic angiotensin II and iNOS levels while increased the aortic eNOS level, and 3) valsartan downregulated the TLR4 and AT1 receptor while upregulated the AT2 receptor mRNA and protein expression.
Valsartan also decreased the aortic p-ERK protein expression. These findings suggest that the therapeutic potential of valsartan in attenuating neointimal hyperplasia and inhibiting the TLR4-iNOS-ERK-AT1 receptor pathway and SRSF1 expression in ballooninjured rat aorta.

The proliferation of VSMCs is pivotal to intimal hyperplasia and finally leads to restenosis after angioplasty and atherogenesis (Yuan et al. 2017). SRSF1 is the prototypical member of the highly conserved SR protein family that functions in key aspects of mRNA 

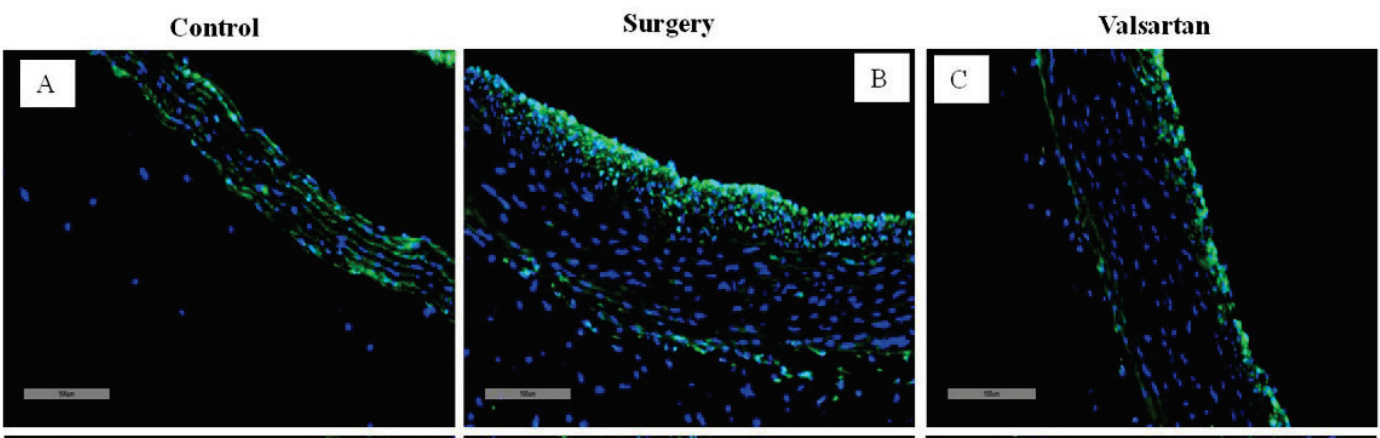

Day 14 after surgery
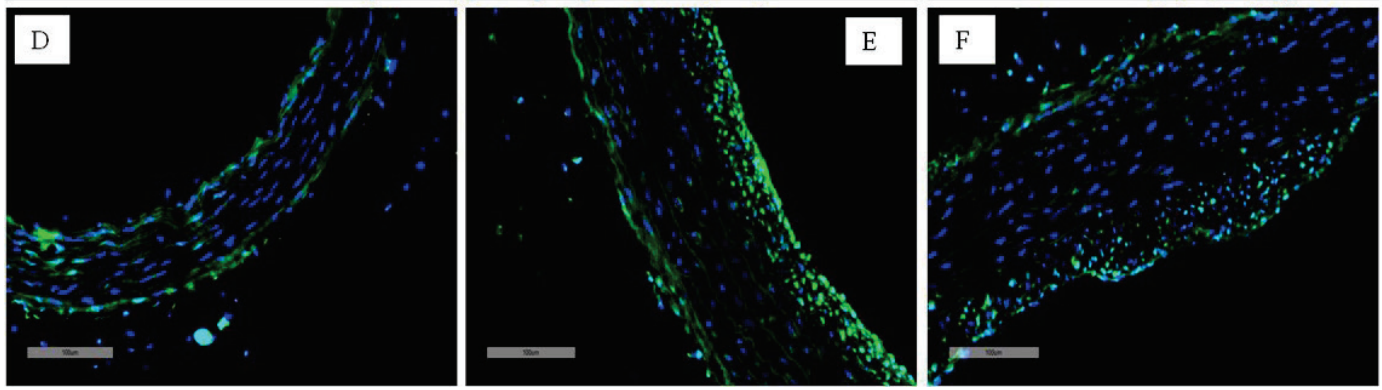

Day 28 after surgery

Fig. 5. Effects of valsartan on protein expression of SRSF1. Protein expression of SRSF1 was determined using immunofluorescence in 14 days (A, B, C) and 28 days (D, E, F).

metabolism. SRSF1 is highly expressed in VSMCs and actively involved in the alternative splicing events that shape the transcriptome of proliferative VSMCs (Llorian et al. 2016). We found that SRSF1 is upregulated in VSMCs during neointima formation, indicating that SRSF1 promotes VSMC proliferation and neointimal thickening. Furthermore, a previous study has manifested that SRSF1 promotes vascular smooth muscle cell proliferation through a D133p53/KLF5 pathway (Xie et al. 2017).Inflammation causes the initiation and development of restenosis. Increasing evidence indicates that inflammatory factor TLR4 activates the gene expression of proinflammatory cytokines (Goulopoulou et al. 2016). As an important transmembrane receptor in the human immune response, TLR4 is widely expressed in cardiomyocytes, endothelial cells, VSMCs, leukocytes, macrophages, etc. Importantly, a higher mRNA and protein expression of TLR4 and its downstream signaling proteins was found in restenosis patients (Liang et al. 2016). TLR4 recognizes and responds against lipopolysaccharides (LPS), and activation of TLR4 by LPS induces the release of inflammatory cytokines and the stimulation of the nuclear factor kappa B (NF-кB) signaling pathway, ultimately initiating or promoting atherosclerotic lesions (Song et al. 2017). Everolimuseluting stents reduce PCI induced increase in the TLR4 expression on the surface of monocytes (Shokri et al. 2015). Notably, TLR4 also plays an important role in nonbacterial inflammatory responses (Vallejo 2011), and may serve as a link between inflammation and atherosclerotic lesions. TLR4 activates p38 mitogenactivated protein kinase (MAPK) and ERK1/2 signaling through myeloid differentiation factor $88(\mathrm{MyD} 88)$ and TIR-domain-containing adapter-inducing interferon- $\beta$ (TRIF) in VSMCs to regulate VSMC functions (Lee et al. 2016). Therefore, inhibition of TLR4 and its upstream signaling molecules provides therapeutic potential for treating restenosis. In the current study, on days 14 and 28 post-surgery, histological analysis demonstrated rat aortic neointimal hyperplasia in balloon-injured rats, which was associated with the increased mRNA and protein expression of TLR4. Treatment with valsartan markedly decreased the TLR4 mRNA and protein expression, concomitant with a reduction in neointimal hyperplasia. Our findings reveal that targeting TLR4 may have therapeutic potential for attenuating neointimal hyperplasia. Endothelial denudation is a prominent characteristic of vascular injury associated with angioplasty. Vascular injury leads to a decreased eNOS production (Hu et al. 2019). In an attempt to offset the absence of eNOS, there is a compensatory upregulation of iNOS within VSMCs (Kibbe, 1999). Inducible NOS contributes to the pathophysiology of inflammatory diseases. In addition, increased TLR4 expression can promote the production of iNOS by increasing the expression of proinflammatory cytokines (Heo et al. 2008). The current study showed the increased aortic levels of iNOS and decreased aortic levels of eNOS in the 
untreated balloon-injured rats. Accordingly, abnormal aortic levels of iNOS and eNOS are reversed by the administration of valsartan. Angiotensin II promotes VSMC proliferation and migration, which contribute to the progression of neointimal hyperplasia. Angiotensin II acts via AT1 receptor and AT2 receptor. Apart from its vascular effects, angiotensin II also triggers an inflammatory response in human VSMCs (Granger et al. 2004, Ji et al. 2009). TLR4 upregulation by angiotensin II contributes to inflammation and endothelial dysfunction (de Batista et al. 2014, Hernanz et al. 2015). Angiotensin $\Pi$ also increased SRSF1 expression at the mRNA and protein levels in a timedependent manner (Xie et al. 2017). ERK1/2 has been demonstrated to be involved in the pathological process of restenosis after coronary vascular injury (Sarov-Blat et al. 2010). Activation of ERK can promote VSMC proliferation or migration as well as accelerate neointimal hyperplasia. It is confirmed that Klotho inhibits proliferation and migration of angiotensin II-induced VSMCs by modulating NF- $\mathrm{kB}$ p65, protein kinase B (Akt), and ERK signaling activities (Yu et al. 2018). Valsartan is a highly selective AT1 receptor blocker (Huang et al. 2014). In this study, we found that it can downregulate the expression of SRSF1 in balloon-injured aorta, and this is not reported before. Consistent with our study, valsartan has been shown to inhibit high-glucoseinduced TLR4 expression (Kintscher et al. 2010) and myocardial ischemia-reperfusion injury associated with TLR4 expression (Yang et al. 2009). Also, our study indicated that valsartan markedly reduces the aortic angiotensin II level, SRSF1 expression, AT1 receptor expression, and ERK protein phosphorylation as well as increases AT2 receptor expression.

In conclusions, this study indicated that the administration of valsartan for both 14 and 28 days after surgery reduced neointimal hyperplasia, and inhibited SRSF1 expression and the TLR4-iNOS-ERK-AT1 receptor pathway in the balloon-injured rat aorta.

\section{Conflict of Interest}

There is no conflict of interest.

\section{Acknowledgements}

This work was supported by the Key Project of Research and Development of Shandong Province (No.2018GSF118241), the National Nature Science Foundation of China (No.81800238) and the Natural Science Foundation of Shandong Province (No. ZR2016HP17).

\section{References}

ALRAIES MC, DARMOCH F, TUMMALA R, WAKSMAN R: Diagnosis and management challenges of in-stent restenosis in coronary arteries. World J Cardiol 9: 640-651, 2017. https://doi.org/10.4330/wjc.v9.i8.640

ARAÚJO PV, RIBEIRO MS, DALIO MB, ROCHA LA, VIARO F, DELLALIBERA JOVILIANO R, PICCINATO CE, ÉVORA PR, JOVILIANO EE: Interleukins and inflammatory markers in in-stent restenosis after femoral percutaneous transluminal angioplasty. Ann Vasc Surg 29: 731-737, 2015. https://doi.org/10.1016/j.avsg.2014.12.006

BUCCHERI D, PIRAINO D, ANDOLINA G, CORTESE B: Understanding and managing in-stent restenosis: a review of clinical data, from pathogenesis to treatment. J Thorac Dis 8: E1150-E62, 2016. https://doi.org/10.21037/jtd.2016.10.93

CHYU KY, DIMAYUGA P, ZHU J, NILSSON J, KAUL S, SHAH PK, CERCEK B: Decreased neointimal thickening after arterial wall injury in inducible nitric oxide synthase knockout mice. Circ Res 85: 1192-1198, 1999. https://doi.org/10.1161/01.RES.85.12.1192

DE BATISTA PR, PALACIOS R, MARTIN A, HERNANZ R, MEDICI CT, SILVA MA, ROSSI EM, AGUADO A, VASSALLO DV, SALAICES M, ALONSO MJ: Toll-like receptor 4 upregulation by angiotensin II contributes to hypertension and vascular dysfunction through reactive oxygen species production. PLoS One 9: e104020, 2014. https://doi.org/10.1371/journal.pone. 0104020

DEN DEKKER WK, CHENG C, PASTERKAMP G, DUCKERS HJ: Toll like receptor 4 in atherosclerosis and plaque destabilization. Atherosclerosis 209: 314-320, 2010. https://doi.org/10.1016/j.atherosclerosis.2009.09.075

FORSTERMANN U, SESSA WC: Nitric oxide synthases: regulation and function. Eur Heart J 33: 829-837, 37a-37d, 2012. https://doi.org/10.1093/eurheartj/ehr304

GRANGER DN, VOWINKEL T, PETNEHAZY T: Modulation of the inflammatory response in cardiovascular disease. Hypertension 43: 924-931, 2004. https://doi.org/10.1161/01.HYP.0000123070.31763.55 
GOUlOPOULOU S, MCCARTHY CG, WEBB RC: Toll-like Receptors in the Vascular System: Sensing the Dangers Within. Pharmacol Rev 68: 142-167, 2016. https://doi.org/10.1124/pr.114.010090

GUIHUA L, WANG L, SANQING J, REN W, LIN Z, DAOKUO Y, RONGJING D: Influence of valsartan-eluting stent on neointima formation. J Cardiovasc Dis Res 1: 19-22, 2010. https://doi.org/10.4103/0975-3583.59980

HADI NR, AL-AMRAN FG, HUSSIEN YA, AL-YASIRI IK, AL-TURFY M: The cardioprotective potential of valsartan in myocardial ischaemia reperfusion injury. Cent Eur J Immunol 40: 159-166, 2015. https://doi.org/10.5114/ceji.2015.52829

HUANG QF, LI Y, WANG JG: Overview of clinical use and side effect profile of valsartan in Chinese hypertensive patients. Drug Des Devel Ther8: 79-86, 2014. https://doi.org/10.2147/DDDT.S38617

IWASHITA M, SAKODA H, KUSHIYAMA A, FUJISHIRO M, OHNO H, NAKATSU Y, FUKUSHIMA T, KUMAMOTO S, TSUCHIYA Y, KIKUCHI T, KURIHARA H, AKAZAWA H, KOMURO I, KAMATA H, NISHIMURA F, ASANO T: Valsartan, independently of AT1 receptor or PPARgamma, suppresses LPSinduced macrophage activation and improves insulin resistance in cocultured adipocytes. Am J Physiol Endocrinol Metab 302: E286-296, 2012. https://doi.org/10.1152/ajpendo.00324.2011

HEO SK, YUN HJ, NOH EK, PARK WH, PARK SD: LPS induces inflammatory responses in human aortic vascular smooth muscle cells via Toll-like receptor 4 expression and nitric oxide production. Immunol Lett 120: 57-64, 2008. https://doi.org/10.1016/j.imlet.2008.07.002

HERNANZ R, MARTINEZ-REVELLES S, PALACIOS R, MARTIN A, CACHOFEIRO V, AGUADO A, GARCÍAREDONDO L, BARRÚS MT, DE BATISTA PR, BRIONES AM, SALAICES M, ALONSO MJ: Toll-like receptor 4 contributes to vascular remodelling and endothelial dysfunction in angiotensin II-induced hypertension. Br J Pharmacol 172: 3159-3176, 2015. https://doi.org/10.1111/bph.13117

HU Z, WANG H, FAN G, ZHANG H, WANG X, MAO J, ZHAO Y, AN Y, HUANG Y, LI C, CHANG L, CHU X, LILI, LI Y, ZHANG Y, QIN G, GAO X, ZHANG B: Danhong injection mobilizes endothelial progenitor cells to repair vascular endothelium injury via upregulating the expression of Akt, eNOS and MMP-9. Phytomedicine 61: 152850, 2019. https://doi.org/10.1016/j.phymed.2019.152850

JANSSENS S, FLAHERTY D, NONG Z, VARENNE O, VAN PELT N, HAUSTERMANS C, ZOLDHELYI P, GERARD R, COLLEN D: Human endothelial nitric oxide synthase gene transfer inhibits vascular smooth muscle cell proliferation and neointima formation after balloon injury in rats. Circulation 97: 1274-1281, 1998. https://doi.org/10.1161/01.CIR.97.13.1274

JI Y, LIU J, WANG Z, LIU N: Angiotensin II induces inflammatory response partly via toll-like receptor 4-dependent signaling pathway in vascular smooth muscle cells. Cell Physiol Biochem 23: 265-276, 2009. https://doi.org/10.1159/000218173

JOVILIANO EE, PICCINATO CE, DELLALIBERA-JOVILIANO R, MORIYA T, EVORA PR: Inflammatory markers and restenosis in peripheral percutaneous angioplasty with intravascular stenting: current concepts. Ann Vasc Surg 25: 846-855, 2011. https://doi.org/10.1016/j.avsg.2011.02.026

KIBBE M, BILLIAR T, TZENG E: Inducible nitric oxide synthase and vascular injury. Cardiovasc Res 43: 650-657, 1999. https://doi.org/10.1016/S0008-6363(99)00130-3

KINTSCHER U, MARX N, MARTUS P, STOPPELHAAR M, SCHIMKUS J, SCHNEIDER A, WALCHER D, KÜMMEL A, WINKLER R, KAPPERT K, DÖRFFEL Y, SCHOLZE J, UNGER T: Effect of high-dose valsartan on inflammatory and lipid parameters in patients with Type 2 diabetes and hypertension. Diabetes Res Clin Pract 89: 209-215, 2010. https://doi.org/10.1016/j.diabres.2010.04.018

LEE GL, WU JY, TSAI CS, LIN CY, TSAI YT, LIN CS, WANG YF, YET SF, HSU YJ, KUO CC: TLR4-Activated MAPK-IL-6 Axis Regulates Vascular Smooth Muscle Cell Function. Int J Mol Sci 17: E1394, 2016. https://doi.org/10.3390/ijms17091394

LIANG S, AIQUN M, JIWU L, PING Z: TLR3 and TLR4 as potential clinical biomarkers for in-stent restenosis in drug-eluting stents patients. Immunol Res 64: 424-430, 2016. https://doi.org/10.1007/s12026-015-8685-6

LI K, DING WH, SHI LB, ZHANG LF, HAN XN, TANG CS: Role of vascular remodeling for urotensin II in rat thoracic aorta after balloon injury. Chin J Pathophys 4: 674-679, 2008.

LI Y, CAI S, WANG Q, ZHOU J, HOU B, YU H, GE Z, GUAN R, LIU X: Valsartan attenuates intimal hyperplasia in balloon-injured rat aortic arteries through modulating the angiotensin-converting enzyme 2-angiotensin-(1-7)Mas receptor axis. Arch Biochem Biophys 598: 11-17, 2016. https://doi.org/10.1016/j.abb.2016.03.028 
LI YH, AN Y, WANG QX, MAN YL, LIU P, REN BB: Effects of valsartan on aortic angiotensin converting enzyme 2 expression after aortic balloon injury in rats. Zhonghua Xin Xue Guan Bing Za Zhi 40: 697-701, 2012.

LI Y, WANG Q, XU Q, CAI S, ZHOU J, REN B, SUN T, LIU X, YU H: Valsartan decreases neointimal hyperplasia in balloon-injured rat aortic arteries by upregulating HO-1 and inhibiting angiotensin II type 1 receptor. Life Sci 110: 70-76, 2014. https://doi.org/10.1016/j.lfs.2014.06.021

LLORIAN, M. GOODING C1, BELLORA N, HALLEGGER M, BUCKROYD A, WANG X, RAJGOR D, KAYIKCI M, FELTHAM J, ULE J, EYRAS E, SMITH CWJ:The alternative splicing program of differentiated smooth muscle cells involves concerted non-productive splicing of post-transcriptional regulators. Nucleic Acids Res 44: 8933-8950, 2016. https://doi.org/10.1093/nar/gkw560

SAROV-BLAT L, MORGAN JM, FERNANDEZ P, JAMES R, FANG Z, HURLE MR, BAIDOO C, WILLETTE RN, LEPORE JJ, JENSEN SE, SPRECHER DL: Inhibition of p38 mitogen-activated protein kinase reduces inflammation after coronary vascular injury in humans. Arterioscler Thromb Vasc Biol 30: 2256-2263, 2010. https://doi.org/10.1161/ATVBAHA.110.209205

SHOKRI M, BAGHERI B, GARJANI A, SOHRABI B, HABIBZADEH A, KAZEMI B, MOVASSAGHPOUR AA: Everolimus-eluting stents reduce monocyte expression of toll-like receptor 4. Adv Pharm Bull 5 (Suppl 1): 643-647, 2015. https://doi.org/10.15171/apb.2015.087

SONG Y, HOU M, LI Z, LUO C, OU JS, YU H, YAN J, LU L: TLR4/NF-kappaB/Ceramide signaling contributes to Ox-LDL-induced calcification of human vascular smooth muscle cells. Eur J Pharmacol 794: 45-51, 2017. https://doi.org/10.1016/j.ejphar.2016.11.029

PARAMASIVAM G, DEVASIA T, JAYARAM A, U K AR, RAO MS, VIJAYVERGIYA R, NAYAK K: In-stent restenosis of drug-eluting stents in patients with diabetes mellitus: Clinical presentation, angiographic features, and outcomes. Anatol J Cardiol 23: 28-34, 2020. https://doi.org/10.14744/AnatolJCardiol.2019.72916

PETERS S: Comparison of efficacy of low- (80 mg/day) and high- (160-320 mg/day) dose valsartan in the prevention of in-stent restenosis after implantation of bare-metal stents in type B2/C coronary artery lesions. Am $\mathrm{J}$ Cardiovasc Drugs 8(2): 83-87, 2008. https://doi.org/10.1007/BF03256585

VALLEJO JG: Role of toll-like receptors in cardiovascular diseases. Clin Sci (Lond) 121: 1-10, 2011. https://doi.org/10.1042/CS20100539

XIE N, CHEN M, DAI R, ZHANG Y, ZHAO H, SONG Z, ZHANG L, LI Z, FENG Y, GAO H, WANG L, ZHANG T, XIAO RP, WU J, CAO CM: SRSF1 promotes vascular smooth muscle cell proliferation through a $\Delta$ 133p53/EGR1/KLF5 pathway. Nat Commun 8: 16016, 2017. https://doi.org/10.1038/ncomms16016

YANG J, JIANG H, YANG J, DING JW, CHEN LH, LI S, ZHANG XD: Valsartan preconditioning protects against myocardial ischemia-reperfusion injury through TLR4/NF-kappaB signaling pathway. Mol Cell Biochem 330: 39-46, 2009. https://doi.org/10.1007/s11010-009-0098-1

YONEDA S, ABE S, KANAYA T, ODA K, NISHINO S, KAGEYAMA M, TAGUCHI I, MASAWA N, INOUE T: Late-phase inflammatory response as a feature of in-stent restenosis after drug-eluting stent implantation. Coron Artery Dis 24: 368-373, 2013. https://doi.org/10.1097/MCA.0b013e32836222ec

YUAN L, DUAN X, DONG J, LU Q, ZHOU J, ZHAO Z, BAO J, JING Z: p21-Activated kinase 4 promotes intimal hyperplasia and vascular smooth muscle cells proliferation during superficial femoral artery restenosis after angioplasty. Biomed Res Int 2017: 5296516, 2017. https://doi.org/10.1155/2017/5296516

YU S, CHEN Y, CHEN S, YE N, LI Y, SUN Y: klotho inhibits proliferation and migration of angiotensin ii-induced vascular smooth muscle cells (VSMCs) by modulating NF-kappaB p65, akt, and extracellular signal regulated kinase (ERK) signaling activities. Med Sci Monit 24: 4851-4860, 2018. https://doi.org/10.12659/MSM.908038

ZAQOUT S, BECKER LL, KAINDL AM: Immunofluorescence staining of paraffin sections step by step. Front Neuroanat 14: 582218, 2020. https://doi.org/10.3389/fnana.2020.582218

ZOU G, ZHU J, LIU Z, WU L, XU R, CHEN H, DENG P, DENG C: Detoxification and activating blood circulation decoction reduces restenosis involving the TLR4/NF- $\mathrm{B}$ pathway after balloon injury. Prostaglandins Other Lipid Mediat 140: 1-8, 2019. https://doi.org/10.1016/j.prostaglandins.2018.11.002 